\title{
URGENSI DAN NILAI-NILAI \\ PENDIDIKAN AGAMA ISLAM DALAM NIAT
}

\author{
Oleh: M. Jauharul Ma'arif, M.Pd.I \\ IAI Sunan Giri Bojonegoro \\ Email: emjemaarifgmail.com
}

\begin{abstract}
Based on the many verses of the Qur'an and the Hadith concerning the intentions and management of the heart, we can conclude that these two things are very important. One should not be surprised if there are many scholars who compile books on the topic of special discussion about the two. Starting something with the intention of causing interest and focus on a charity that affects the readiness of the heart to do it. This readiness is important because the heart is a place where ikhläs as the mouth of all worship is. With the heart ready it is expected that a 'charity can be carried out to the maximum. The intention is not just a ritual of worship, but if worship is carried out with full appreciation, there will appear a lot of Islamic religious education values obtained. Among them are submission and obedience to religious orders, obeying regulations, growing enthusiasm to achieve good goals, determination and enthusiasm towards goodness, patience and a strong willingness to do something good even though heavy and difficult, awareness to improve the quality of faith and devotion, concern for self and the environment, vigilance to avoid or deal with liver disease, discipline, wisdom, love and obedience to religious orders.
\end{abstract}

Keywords: urgency, Islamic religious education values, intention

\section{Pendahuluan}

Memang Al Qur'an tidak menyebutkan kata niyyah secara eksplisit, namun implisit ada beberapa beberapa istilah yang digunakan oleh Al Qur'an dalam banyak ayat, misalnya: irādah al ākhirah, (misalnya QS. 3: 152), irādah thawāb al ākhirah (QS. 3: 145), irādah ḥarth al ākhirah (QS. 42: 20), irādah wajh Allāh (QS. 30: 39), ibtigha' wajhih (QS. 2: 272) dan ibtghā' mardàtih (QS. 2: 207). ${ }^{1}$

Hadits yang salah satu fungsinya sebagai penjelas Al Qur'an juga banyak membicarakan tentang niat. Rasulullah SAW menyampaikan bahwa sesungguhnya amal tergantung pada niatnya, ${ }^{2}$ manusia akan di ba'th sesuai niat mereka ${ }^{3}$, Allah SWT tidak

\footnotetext{
${ }^{1}$ Yūsuf Al Qarḍ̄wy, Tamyīz Fiqh Al Sulūk ila Allāh fi Ḍa' al Qur'ān wa al Sunnah fi al Tarīq ila Allāh: al Niyyah wa al Ikhlas, (Mu'assasah al Risālah), hlm. 8

${ }^{2}$ HR. Al Bukhäry, Sạ̣ị̣ al Bukhāry Juz 1, (Dār Ṭawq al Najāh, 1422 H), hlm. 6

${ }^{3}$ HR. Ibn Mājah, Sunan Ibn Mājah Juz 2, (Beirut: Dār al Fikr), hlm. 1414 
melihat pada jasad kita, namun Allah SWT melihat apa yang ada di dalam hati kita. ${ }^{4}$ Bahkan di dalam hadits qudsy, Rasulullah SAW menyampaikan kepada kita bahwa jika ada seseorang berniat melakukan kebaikan maka langsung dicatat sebagai satu kebaikan dan jika dia melakukan maka (minimal) dicatat sebagai sepuluh kebaikan, namun jika berniat akan melakukan hal yang jelek maka tidak dicatat sampai dia merealisasikan apa yang diniatkannya, maka dicatat sebagai satu kejelekan. ${ }^{5}$

Dari banyaknya ayat Al Qur'an maupun Hadits Nabi yang mengingatkan tentang niat tersebut, kita dapat menyimpulkan bahwa niat dan kemampuan manajemen qalbu itu sangat penting. Sehigga tidak mengherankan jika banyak ulama yang menyusun kitab dengan topik pembahasan khusus mengenai niat, ikhlas dan pengelolaan hati. Beberapa di antaranya bisa dilihat di Daftar Pustaka tulisan ini.

Ibnu Ḥazm (dalam 'Umar Sulaymān) mengatakan bahwa kedudukan niat seperti ruh bagi tubuh. Niat merupakan rahasia dan ruh ibadah. Sangatlah mustahil ada perbuatan yang tidak memiliki ruh (baca: niat), sebab perbuatan yang tidak memiliki niat sama artinya dengan tubuh yang tidak memiliki ruh. ${ }^{6}$ Begitu pentingnya niat sehingga para ulama salaf mengajari putra-putrinya mengenai niat sebagaimana mereka mengajarkan Al Fatihah. ${ }^{7}$

Niat dianggap agung karena sumber dan motivatornya, yaitu hati. Hati merupakan pokok dari seluruh anggota tubuh dan ia (menurut sebagian pendapat) merupakan suatu tempat di mana akal berada. Hati melakukan pekerjaan yang besar dan berbahaya seperti iman, kufur, ridla, dan takabbur. Segala perbuatan manusia yang tampak hanyalah bentuk lahiriah yang merupakan cerminan dari hati yang tersembunyi. Karena hatilah yang memerintah atau melarang. Seluruh anggota tubuh taat kepada hati sebagaimana taatnya tentara kepada komandannya. ${ }^{8}$

Selain itu, pokok ibadah adalah ikhlas (baca: niat), sedangkan ibadah lainnya merupakan cabang daripada ikhlas. Ikhlas berada di dalam hati dan anggota badan yang dhahir mengikuti yang bathin. Jika anggota badan yang bathin berperilaku lurus, maka

\footnotetext{
${ }^{4}$ HR. Muslim bin Hajjāj, Sahịhh Muslim Juz 8, (Beirut: Dār al Āfāq al Jadidah), hlm. 11

${ }^{5}$ HR. Muslim bin Hajjāj, Sahịh Muslim Juz 1... hlm. 82

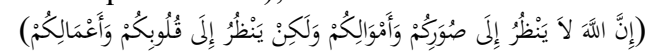

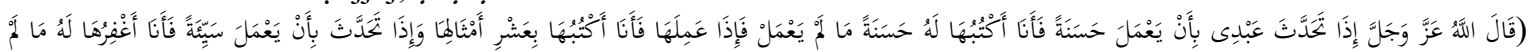

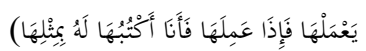

${ }^{6}$ Umar Sulaymān al Ashqar, al Niyyāt fi al 'Ibādāt terj. Oleh Faisal Saleh, (Jakarta: Gema Insani Press, 2005), hlm. 49

${ }^{7}$ Muhammad bin 'Alawy bin Umar Al 'Idrūs, Kitāb al Niyyāt, (Yaman: Tarīm li al Dirāsāt wa al Nashr, 1424 H/2003 M), hlm. 6

${ }^{8}$ Umar Sulaymān al Ashqar, al Niyyāt ... hlm. 77
}

15 | At-Tuhfah: Jurnal Studi Keislaman. Vol.9, No.1, 2020 
anggota badan yang dhahir mengikuti secara otomatis. Begitu pula sebaliknya. Oleh karena itu sebaiknya memiliki keinginan yang kuat dan maksimal untuk menyelamatkan bathinnya dan meluruskannya. Sebab Istiqāmah bermuara dari bathin. ${ }^{9}$ Rasululla SAW bersabda:

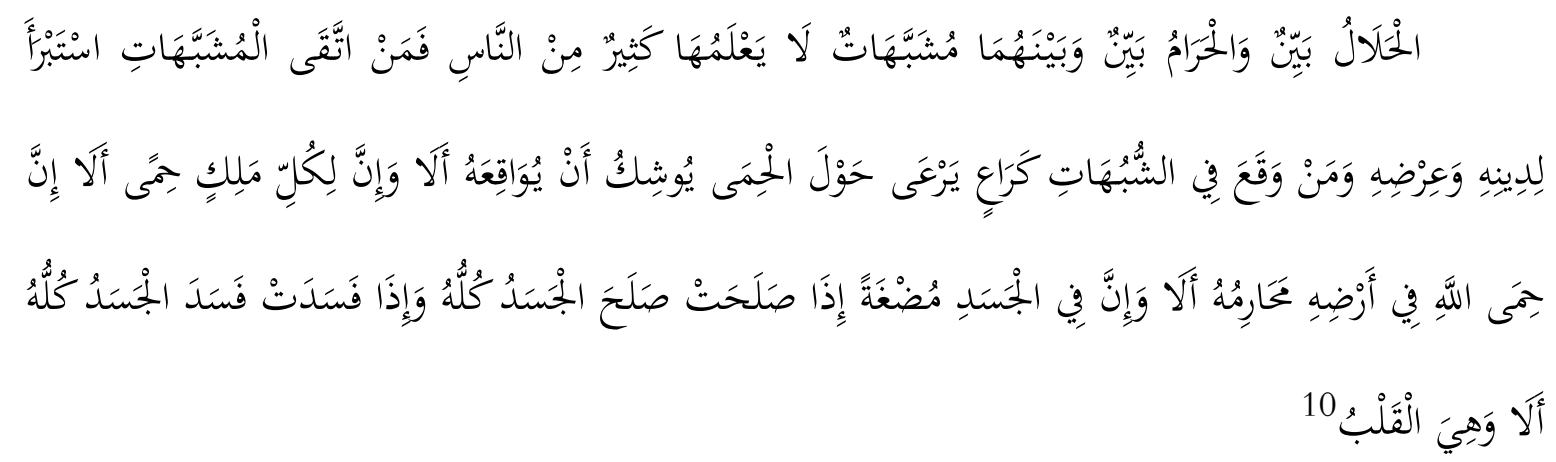

Bukti lain bahwa pembahasan tentang niat itu penting adalah pendapat para ulama bahwa hadits tentang niat merupakan salah satu pokok dari beberapa pokok ajaran Islam. Imām al Shāfi'iy dan Imām Ahmad bin Hanbal- menyatakan bahwa hadits tentang niat sebagai sepertiga dari Islam, sebab niat merupakan satu di antara muara ajaran Islam, yaitu: qawl, 'amal dan niyyah. ${ }^{11}$

\section{Hakekat dan Urgensi Niat}

Dari segi bahasa, niat merupakan masdar dari nawā-yanwī yang berarti qasada atau i'taqada. Niat juga memiliki arti arah yang dituju oleh musafir. ${ }^{12}$ Niat juga berasal dari kata $A l$ Nawā yang artinya berpindah dari suatu tempat ke tempat yang lain. ${ }^{13}$ Ada pula yang berpendapat bahwa kata niat mushtaq dari An Naā yang artinya jauh. Sebab niat berada di anggota badan yang paling jauh, yaitu hati. ${ }^{14}$ Hakekat niat adalah qasd al shai wa 'azm al qalb 'alaih. ${ }^{15}$ Dari uraian tersebut dapat diketahui bahwa makna niat menurut para ahli bahasa tidak keluar dari makna al 'azm, al qasd dan al irādah. ${ }^{16}$

Niat adalah ungkapan tentang al irādah (kehendak) dan al qạsd (maksud). Al irādah adalah sebutan untuk al 'azm (kesungguhan hati) dan al qasd. Niat dan al 'azm

\footnotetext{
${ }^{9}$ Ibn Al Hājj, al Madkhal ilā Tanmiyah al A'māl Juz 1, (Kairo: Maktabah Dār al Turāth), hlm. 7

10 Al Bukhāry, Sahịh al Bukhāry Juz 1... hlm. 20

${ }^{11}$ Muhammad bin Yūnus Al Suwaisy, Majāl al Niyyah fi Al Fiqh Al Islāmy, (Tunisia: Dār Sukhnūn li al Nashr wa al Tawzì', 1431 H/2010 M), hlm. 26

12 Assayyid Ahmad Bik al Ḥusainy, Nihāyah al Aḥkām fi Bayān mā li al Niyyah min al Aḥkām, (Mesir: Matba'ah al Kubrā al Amiriyyah, 1320 H/1903 M.), hlm. 7

${ }^{13}$ Muhammad bin Yünus Al Suwaisy, Majāl ... hlm. 18

${ }^{14}$ Assayyid Ahmad Bik al Husainy, Nihāyah ... hlm. 7

${ }^{15}$ Assayyid Ahmad Bik al Ḥusainy, Nihāyah ... hlm. 7

${ }^{16}$ Muhammad bin Yünus Al Suwaisy, Majāl ... hlm. 18
}

At-Tuhfah: Jurnal Studi Keislaman. Vol.9, No.1, 2020 | 16 
ada mendahului perbuatan dan menjadi sebab dalam merealisasikan perbuatan. Sedangkan al qasd adalah sebutan untuk keinginan yang berbarengan dengan perbuatan. $^{17}$

Jadi pekerjaan yang diniati ada 2, yaitu istiqbāly (akan dilakukan) dan Hāly (saat ini dilakukan berbarengan dengan niat). Jika niat dikaitkan dengan pekerjaan yang istiqbāly maka disebut 'azm, sedang jika dikaitkan dengan pekerjaan yang Hâaly maka disebut qasd. ${ }^{18}$

Dalam istilah ilmu Fikih, niat didefinisikan sebagai suatu kesengajaan dalam hati untuk melakukan sesuatu pekerjaan bersamaan dengan awal pekerjaan tersebut. ${ }^{19}$ Al Zuhaily mendefinisikan sebagai suatu 'azm (tekat yang kuat) di dalam hati untuk melakukan 'amal baik wajib maupun sunnah. ${ }^{20}$

Berbeda dengan ahli fikih yang membagi niat menjadi dua, Mashrū'ah (niat yang baik) dan Ghayr al Mashrü'ah (niat yang tidak baik) atau istilah lainnya adalah al bä'ith al sayyi ${ }^{21}$, niat menurut Ahli Tasawf hanya mengarah kepada hal yang baik. Definisi niat yang dikemukakan oleh salah seorang ulama tasawf adalah:

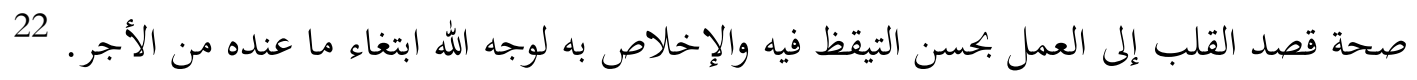

Ada pula ahli tasawuf yang mendefinisikan bahwa niat adalah keikhlasan dalam berbakti dan beribadah. ${ }^{23}$ Ada pula yang mengatakan bahwa niat merupakan kecenderungan hati pada hal yang baik. ${ }^{24}$ Assayyid Murtada al Zubaydy berpendapat bahwa niyyah adalah melakukan sesuatu karena Allah atau mengharapkan sesuatu dari Allah. Jika yang diharapkan adalah makhluk atau sesuatu dari makhluk, maka disebut umniyyah. ${ }^{25}$

\section{Hukum dan Dasar Hukum Niat}

Hukum niat adalah wajib pada suatu ibadah yang tidak sah jika tanpa niat dan sunnah pada sesuatu yang sah dilakukan tanpa niat seperti meninggalkan sesuatu

\footnotetext{
${ }^{17}$ Syekh Yahya ibn Hazah Al Yamāny, Tasfiyah al Qulūb min Daran al Awzār wa al Dhunūb (Pelatihan Lengkap Tazkiyah al Nafs terj. oleh Maman Abdurrahman as Segaf), (Jakarta: Zaman, 2012), hlm. 468

${ }^{18}$ Assayyid Ahmad Bik al Ḥusainy, Nihāyah ...hlm. 7. Lihat pula Muhammad bin Yūnus Al Suwaisy, Majāl ... hlm. 28 dan Al Yūsuf Al Qarḍāwy, Tamyīz ... hlm. 13

${ }^{19}$ Al Shaikh Sulaimān al Jamal, Hāshiyah al Jamal Juz 2, (Beirut: Dār al Fikr), hlm. 169. Lihat pula Abu Bakr al Dimyāti, I'ānah al Tâlibīn Juz 1, (Mawqi' Ya'sūb), hlm. 149

${ }^{20}$ Wahbah al Zuhaily, Al Fiqh Al Islāmy wa Adillatuh Juz 1, (Damaskus: Dār al Fikr), hlm. 126

${ }^{21}$ Wahbah al Zuhaily, Al Fiqh ...hlm. 122

${ }^{22}$ Muhammad bin Yünus Al Suwaisy, Majāl ... hlm. 44

${ }^{23}$ Muhammad bin Yūnus Al Suwaisy, Majāl ... hlm. 44

${ }^{24}$ Al Ghazāly, Al Arba'īn fì Usūil al Dìn, (Damaskus: Dār al Qalam, 1424 H/2003 M), hlm. 226

${ }^{25}$ Al Shaikh Ihsān Muhammad Daḥlān, Sirāj al Ṭālibīn Juz 1, (Dār al Fikr), hml. 83
}

17 | At-Tuhfah: Jurnal Studi Keislaman. Vol.9, No.1, 2020 
yang makruh atau yang haram. ${ }^{26}$ Meski ibadah tersebut sudah sah tanpa niat, namun tidak mendapat pahala jika tidak ada niat. ${ }^{27}$

Ketika kita membaca Al Qur'an ayat per-ayat, kita tidak akan mendapati satu ayatpun yang di situ terdapat kata niat. Namun ada ayat yang menunjukkan hukum niat sebagai dalil yang tidak sarih, yakni di Sürah Al Bayyinah (98: 5):

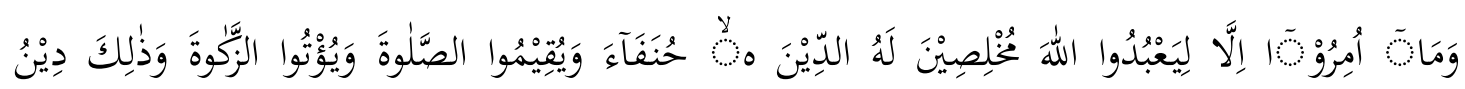
الْقِيَمَمَةِِِِ

Padahal mereka hanya diperintah menyembah Allah dengan ikhlas menaati-Nya semata-mata karena (menjalankan) agama, dan juga agar melaksanakan salat dan menunaikan zakat; dan yang demikian itulah agama yang lurus (benar). ${ }^{28}$

Beberapa mufassir, di antaranya adalah Ibn 'Abd al Salām, menjelaskan bahwa maksud kata mukhlisin dalam ayat tersebut adalah niat melakukan ibadah dengan ikhlas. ${ }^{29}$ Begitu pula para fuqahā', banyak di antara mereka yang menjelaskan bahwa yang dimaksud dengan ikhlās pada ayat tersebut adalah niat. ${ }^{30}$ Selain QS. 98: 5 ini ada beberapa dalil terkait niat yang sudah dijelaskan di atas.

Dalil Hadits tentang niat juga banyak ditemukan sebagaimana dikemukakan di atas. Di antara Hadits yang paling terkenal tentang niat adalah:

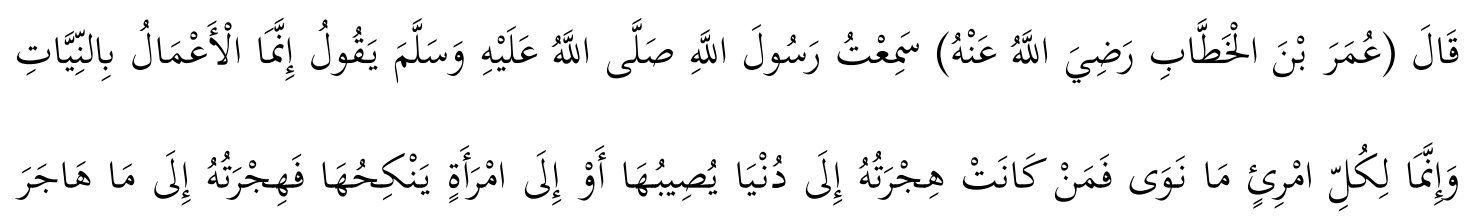

Berkata Umar ibn Khațāa RA, saya mendengar Rasulullah SAW bersabda: "Sesungguhnya amal perbuatan tergantung pada niat dan sesungguhnya bagi setiap orang apa yang ia niatkan”.

\footnotetext{
${ }^{26}$ Assayyid Ahmad Bik al Ḥusainy, Nihāyah ... hlm. 10

27 Assayyid Ahmad Bik al Ḥusainy, Nihäyah ...hlm. 11

${ }^{28}$ www.quran.kemenag.go.id

29 Lihat misalnya Ibn 'Abd al Salām, Tafsìr Ibn 'Abd al Salām Juz 8, hlm. 79

${ }^{30}$ Al Qarāfy, al Umniyyah fi Idrāk al Niyyah, (Riyaḍ: Maktabah al Haramayn, 1408 H/1988 M), hlm. 138

${ }^{31}$ Al Bukhāry, Sahịh al Bukhāry Juz 1... hlm. 6
}

At-Tuhfah: Jurnal Studi Keislaman. Vol.9, No.1, 2020 | 18 


\section{Syarat Niat}

Niat harus memenuhi beberapa syarat, di antaranya adalah bahwa orang yang akan melaksanakan niat harus beragama Islam, mencapai derajat tamyiz, mengetahui ibadah yang akan diniati dan tidak melakukan sesuatu yang bertolak belakang dengan niatnya. ${ }^{32}$

\section{Waktu dan Tempat Pelaksanaan Niat}

Waktu pelaksanaan niat adalah bersamaan dengan awal ibadah kecuali beberapa ibadah seperti puasa wajib, zakat, menyembelih hewan qurbān atau mengeluarkan kaffarah. Niat dalam puasa wajib harus dilakukan sebelum melakukan puasa, yakni pada pada malam hari sebelum keesokannya dilakukan puasa. Sedangkan niat pada ibadah zakat, menyembelih hewan qurbān atau mengeluarkan kaffarah dapat dilakukan pada waktu memisahkan harta/hewan qurban atau pada waktu melaksanakannya (menyerahkan zakat atau menyembelih hewan qurbān). ${ }^{33}$

Niat yang bertempat di dalam hati, adapun mengucapkan dengan lisan dalam rangka untuk menuntun hati hukumnya sunnah bahkan ada qawl da'ïf yang mewajibkannya. ${ }^{34}$

\section{Obyek Niat}

Karena tujuan niat adalah untuk mendapatkan pahala dari ketaatan dan melaksanakan perintah, maka obyek niat ada 3, yaitu:

a. Al Ta's'àt (ibadah/ketaatan) yang mencakup: 'aqīdah (keyakinan), al 'Ibādàt al Wajibah (Ibadah wajib), dan al Qurubāt (ibadah sunnah)

b. Al Turūk (meninggalkan larangan) yang meliputi meninggalkan hal yang haram dan makruh.

c. Al Mubāhăt (hal-hal yang boleh). ${ }^{35}$

\section{Maksud Disyariatkannya Niat}

Niat disyariatkan dengan maksud untuk membedakan antara 'ibādah dan 'àdah atau antara 'ibādah wajib dan 'ibādah sunnah. ${ }^{36}$ Jadi ibadah yang tidak ada

${ }^{32}$ Assayyid Ahmad Bik al Husainy, Nihāyah hlm. 130-133

${ }^{33}$ Assayyid Ahmad Bik al Ḥusainy, Nihāyah ...hlm. 10

${ }^{34}$ Assayyid Ahmad Bik al Ḥusainy, Nihăyah ... hlm. 10

${ }^{35}$ Muhammad bin Yünus Al Suwaisy, Majāl ... hlm. 31-34

19 | At-Tuhfah: Jurnal Studi Keislaman. Vol.9, No.1, 2020 
kesamaan dengan adah seperti iman, tawakkal dll tidak wajib niat. ${ }^{37}$ Boleh jadi perbuatan yang dilakukan sama, namun yang satu mendapat pahala sebab niat melakukan perintah Allah, sedang yang satu tidak mendapat pahala sebab tidak disertai niat. Bisa jadi sama-sama melaksanakan shalat, namun yang satu terhitung wajib dan yang lain terhitung sunnah karena niatnya.

\section{Anjuran Memperbanyak Niat}

Kita dianjurkan untuk sedapat mungkin memperbanyak niat di setiap amal yang kita lakukan, sehingga dengan satu 'amal kita niatkan beberapa niat yang berbeda $^{38}$ dan kita akan mendapat pahala sesuai dengan banyaknya niat kita. Sebagai contoh, ketika kita berangkat ke masjid maka kita kita niat melakukan 8 hal, yaitu: (1) "mengunjungi" Allah di "rumah-Nya", (2) menghasilkan perjanjian dengan Allah untuk memasukkannya ke dalam golongan Ahl al Kirām wa al Shafăah, (3) menambah bekal agar tidak termasuk orang yang merugi di akherat, (4) bersegera memenuhi panggilan Allah, (5) menunaikan amanah dari Allah, (6) memakmurkan masjid, (7) Amr Ma'ru?f Nahy Munkar, dan (8) meninggalkan yang bersifat duniawi menuju ukhrawy. ${ }^{39}$ Selain itu masih bisa ditambahkan beberapa niat yang lain, misalnya: niat belajar atau mengajarkan kebaikan ${ }^{40}$, i'tikăf ${ }^{41}$, meninggalkan dosa karena malu kepada Allah, mengkhususkan waktu untuk berdzikir kepada $\mathrm{Allah}^{42}$ dan lain-lain. Semakin banyak niat, semakin banyak pula pahala yang kita dapatkan.

\section{Urgensi dan Manfaat Niat}

Niat merupakan salah satu yang sangat urgen, sebab niat akan menjadi kekuatan yang mengarahkan manusia pada kebahagiaan hakiki. Selain itu, minimal ada 4 hal yang menunjukkan urgensi niat, di antaranya adalah:

\footnotetext{
${ }^{36}$ Assayyid Ahmad Bik al Ḥusainy, Nihāyah ...hlm. 10 lihat pula Al Qarāfy, al Umniyyah ... hlm. 141

${ }^{37}$ Al Qarāfy, al Umniyyah ...hlm. 143

${ }^{38}$ Ibn Al Hājj, al Madkhal ... hlm. 12

${ }^{39}$ Muhammad bin 'Alawy bin Umar Al 'Idrūs, Kitāb al... hlm. 7-15

${ }^{40}$ HR. Al Ḥākim, al Mustadrak 'ala al Șạhịhaīn Juz 1, (Beirut: Dār al Kutub al 'Ilmiyyah, 1411 H/1990 M), hlm. 169

قال رسول الله صلى الله عليه و سلم : من غدا إلى المسجد لا يريد إلا ليتعلم خيرا أو يعلمه كان له أجر معتمر تام العمرة فمن راح إلى المسجد لا يريد إلا ليتعلم خيرا أو يعلمه فله أجر حاج تام الحجة 316

${ }^{41}$ HR. Al Suyūty, Al Khasăàịs al Kubrā Juz 2, (Beirut: Dār al Kutub al 'Ilmiyyah, 1405 H/1985 M), hlm. عن أنس أن النبي \}صلى الله عليه وسلم\{ قال لعثمان بن مظعون إذها لم تكتب علينا الرهبانية وإن رهبانية أمتي الجلوس في المساجد انتظارا للصلوات والحج والعمرة

42 Ibn Al Hājj, al Madkhal ... hlm. 13
}

At-Tuhfah: Jurnal Studi Keislaman. Vol.9, No.1, 2020 | 20 
a. Niat merupakan sesuatu yang samar dalam diri seseorang (Mengelola sesuatu yang samar lebih sulit daripada mengelola sesuatu yang tampak)

b. Tidak ada yang mengetahui (apa yang kita) niat(kan) kecuali Allah SWT

c. Amal tidak sah tanpa niat

d. Niat merupakan pembeda antara amal duniawi dan ukhrawi serta pembeda antara tingkatan ibadah. ${ }^{43}$

Banyak hal yang didapatkan dari niat, di antaranya adalah:

a. Amal menjadi ringan ${ }^{44}$

b. Niat menjadi sebab turunnya taufiq ${ }^{45}$ dan ma'ūnah Allah ${ }^{46}$

c. Niat menggugah anggota badan untuk bergerak (beribadah). ${ }^{47}$

d. Amal yang tampak sepele akan menjadi agung karena niat. ${ }^{48}$

e. Satu 'amal bisa mendapat banyak pahala sebanyak yang diniatkan. ${ }^{49}$ Imam Ahmad bin Hanbal meriwayatkan sebuah hadits tentang ini.

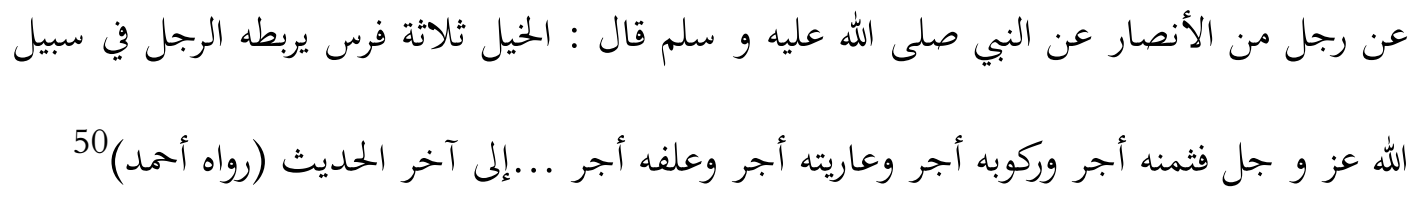

\section{Nilai Pendidikan Agama Islam Dalam Niat}

Niat merupakan irädah ${ }^{51}$ (kehendak) dan inbi' àth al nafs (pancaran jiwa) yaitu raghbah (hasrat) dan mail (kecenderungan) kepada sesuatu yang sesuai dengan gharadl baik sekarang maupun yang akan datang ${ }^{52}$. Definisi al G̣azāly ini senada dengan definisi niat menurut ahli psikologi pendidikan. Menurut mereka niat merupakan bagian dari al 'amal al irādy (pekerjaan yang dikehendaki) yang muncul karena kebutuhan dan keinginan untuk mewujudkan apa yang dikehendaki. ${ }^{53}$

\footnotetext{
${ }^{43}$ Muhammad bin Yūnus Al Suwaisy, Majāl ... hlm. 37-39

${ }^{44}$ Assayyid Muhammad Al Ḥusaini Al Zubaidy, Ithaf Al Sādah Al Muttaqīn Juz 10, (Beirut: Muassasah al Tarikh al Araby, 1414 H/1994 M), hlm. 3

${ }^{45}$ Assayyid Muhammad Al Husaini Al Zubaidy, Ithaf ... hlm. 6

${ }^{46}$ Assayyid Muhammad Al Ḥusaini Al Zubaidy, Ithaf ...hlm. 11

${ }^{47}$ Muhammad bin Yünus Al Suwaisy, Majāl ... hlm. 45

${ }^{48}$ Muhammad bin 'Alawy bun Umar Al 'Idrūs, Kitāb al ... hlm. 6

${ }^{49}$ Ibn Al Hājj, al Madkhal ... hlm. 15

${ }^{50}$ Ahmad bin Hanbal, Musnad al Imām Ahmad bin Hanbal Juz 4, (Kairo: Mu'assasah Qurtubah), hlm. 69

${ }^{51}$ Assayyid Ahmad Bik al Husainy, Nihāyah ... hlm. 10

${ }^{52}$ Assayyid Muhammad Al Husaini Al Zubaidy, Ithaf ... hlm. 13

${ }^{53}$ Muhammad bin Yünus Al Suwaisy, Majāl ... hlm. 20
}

21 | At-Tuhfah: Jurnal Studi Keislaman. Vol.9, No.1, 2020 
Al 'amal al Irādy ini tidak mungkin terlaksana tanpa 3 hal, yaitu: pengetahuan, kehendak dan kemampuan. Karena tidak mungkin seseorang berkehendak untuk melakukan sesuatu tanpa ada pengetahuan tentang sesuatu itu sebelumnya. Begitu pula kehendak tersebut hanya menjadi sebuah keinginan jika tidak ada kemampuan untuk merealisasikannya. ${ }^{54}$ Jika irädah (kehendak) sudah muncul, maka qudrah (kemampuan) untuk menggerakkan anggota badan juga bangkit. Jadi qudrah membantu irädah dan irādah tunduk pada keyakinan dan pengetahuan. ${ }^{55}$

Niat merupakan elemen rohani atau benih manusia. Dari niat itulah muncul perilaku baik yang positif maupun negatif. Ketika kita meneliti orang yang sukses di sekitar kita, dan menengok sisi bathiniahnya, maka kita akan menemukan bahwa ada suatu rahasia dibalik kesuksesannya. Mungkin kita menemukannya sebagai orang yang tidak egois, tidak mudah mengeluh, selalu berpikir positif dan lain sebagainya. ${ }^{56}$

Niat berpengaruh pada diri manusia baik pada kejadian yang nampak maupun tidak nampak. ${ }^{57}$ Ketika terjadi konflik antara ide dengan etika, maka niat dapat membantu menyelesaikannya. ${ }^{58}$ Niat akan mengalir dan berubah dari pengetahuan menjadi potensi kemampuan. ${ }^{59}$ Pada gilirannya niat akan membentuk karakter manusia. ${ }^{60}$ Dan memang pada hakekatnya, niat merupakan karakter pemikiran yang ada di dalam diri manusia. ${ }^{61}$ Karakter tersebut akan terbentuk dari nilai-nilai yang didapatkan dari ibadah.

Salah satu metode pendidikan di dalam Islam adalah mengarahkan pemeluknya untuk melakukan suatu ibadah yang tujuan akhirnya adalah untuk membiasakannya melakukan hal-hal yang utama dan menjauhkan dari hal-hal tidak baik yang dilarang oleh agama serta untuk meningkatkan kualitas hubungan dengan Allah SWT. ${ }^{62}$

Ibadah terdiri dari 2 komponen, yaitu niat dan amal. Niat lebih utama daripada amal yang dilakukan anggota badan lahir karena amal anggota badan lahir adalah tujuan antara, sementara tujuan utamanya adalah ta'thir fil qalb agar condong pada kebaikan dan lari dari hal yang buruk. Sujud bukanlah meletakkan jidat di lantai, tujuan utamanya sifat bakhil dan

\footnotetext{
${ }^{54}$ Muhammad bin Yūnus Al Suwaisy, Majāl ...hlm. 20

${ }^{55}$ Muhammad bin Yūnus Al Suwaisy, Majāl ... hlm. 21

${ }^{56}$ Nāyif al Juhany, Kārma al Niyyah, (Saudi Arabia: Shirkah Ikshif Dhātak, 2017), hlm. 55

${ }^{57}$ Nāyif al Juhany, Kārma ...hlm. 45

${ }^{58}$ Näyif al Juhany, Kärma ... hlm. 47

${ }^{59}$ Nayif al Juhany, Kärma ...hlm. 33

${ }^{60}$ Näyif al Juhany, Kärma ..., hlm. 39

${ }^{61}$ Näyif al Juhany, Kärma ...hlm. 23

${ }^{62}$ Khālid al Ḥāzimy, Usūil Al Tarbiyah Al Islāmiyyah, (Madinah: Dār Ālam Al Kutub, 1420 H/2000 M), hlm. 58 lihat pula Ibn Kathīr, Tafsìr Al Qur'ān Al Ażìm Juz 6, (Dār Ṭaibah li An Nashr wa al tawzì', 1420 H/1999 M), hl. 280
}

At-Tuhfah: Jurnal Studi Keislaman. Vol.9, No.1, 2020 | 22 
tujuan akhirnya Khudu al Qalb. Zakat bukan hanya sekedar izālatul milk, akan tetapi tujuan utamanya adalah memutus 'alāqah al qalb dari harta. ${ }^{63}$

Di antara nilai pendidikan agama Islam yang terdapat dalam niat adalah:

1. Tunduk pada perintah ${ }^{64}$ dan taat pada aturan agama ${ }^{65}$

Dengan melakukan niat, maka orang yang melakukan suatu kegiatan menyadari dengan sepenuh hati bahwa dia melakukan hal tersebut karena perintah agama sebagai bentuk ketaatan kepada Allah SWT. Orang yang melakukan shalat dhuhur misalnya, dalam niatnya ia akan menyatakan "fardan" yang artinya dia dengan penuh kesadaran melakukan aturan yang wajib dilakukanoleh seorang Muslim.

Jika hal ini dilakukan berulang-ulang dengan penuh penghayatan maka akan timbul karakter tunduk dan patuh pada perintah dan aturan agama. Sebagaimana disampaikan oleh Profesor Wayne W. Dier bahwa niat akan menumbuhkan karakter disiplin yang pada tahap selanjutnya akan memunculkan kebijaksanaan. Selanjutnya kebijaksanaan akan menumbuhkan cinta dan fase terakhir adalah munculnya karakter patuh. ${ }^{66}$

2. Tumbuhnya semangat ${ }^{67}$ dan tekat melakukan hal yang baik dan positif ${ }^{68}$

Muara semua ibadah adalah untuk kebaikan pribadi seorang muslim, kemlompok maupun lingkungan tempat dia berada secara umum. Karena Islam merupakan rahmatan li al 'ālaminn. Niat melakukan ibadah pada gilirannya akan menumbuhkan semangat, tekun untuk melakukan, menebar manfaat kepada diri, dan lingkungan.

3. Kesabaran dan kemauan yang kuat untuk melakukan sesuatu yang berat dan sulit. ${ }^{69}$

Di satu sisi, ibadah merupakan anugerah. Namun di sisi lain terkadang kita memandangnya sebagai kulfah (beban yang berat). Meski ibadah merupakan kulfah, setiap muslim akan berusaha untuk melaksanakannya. Hal ini akan berdampak positif pada tumbuhnya daya juang dalam menghadapi permasalahan yang berat sulit.

\footnotetext{
${ }^{63}$ Al Ghazāly, Al Arba'īn ...hlm. 226

${ }^{64}$ Muhammad bin Yünus Al Suwaisy, Majāl ... hlm. 44

${ }^{65}$ Muhammad bin Yünus Al Suwaisy, Majāl ... hlm. 46

${ }^{66}$ Wayne W. Dier, The Power of Intention terj. Quwwah al 'Azimah, (Saudi Arabia: Maktabah Jarir, 2008), hlm. 15-16

${ }^{67}$ Syekh Yahya ibn Hazah Al Yamāny, Tasfiyah ...hlm. 478

${ }^{68}$ Assayyid Muhammad Al Husaini Al Zubaidy, Ithaf ... hlm. 12

${ }^{69}$ Muhammad bin Yünus Al Suwaisy, Majāl ... hlm. 45-46
}

23 | At-Tuhfah: Jurnal Studi Keislaman. Vol.9, No.1, 2020 
4. Kesadaran untuk meningkatkan kualitas keimanan dan ketaqwaan ${ }^{70}$

Melakukan ibadah merupakan bentuk ketaatan dan ketundukan kepada Allah SWT. Rasa tunduk dan patuh kepada Allah SWT ini akan meningkatkan keimanan dan pada gilirannya akan menumbuhkan ketaqwaan.

5. Kepedulian pada diri sendiri maupun lingkungan. ${ }^{71}$

Secara umum, ada dua fungsi ibadah, yakni ritual dan sosial. Dalam fungsi ritualnya, ibadah merupakan kewajiban dan tanggung jawab seorang hamba kepada Tuhannya. Ibadah dilakukan, salah satunya, adalah untuk melaksanakan kewajiban dan mencapai kebahagiaan diri pribadi seorang muslim. Sedang dalam fungsi sosialnya, ibadah diharapkan mewujudkan lingkungan sosial yang baik. Dengan melaksanakan ibadah disertai penghayatan niat ibadah tersebut akan menumbuhkan kepedulian pada seorang muslim pada diri dan lingkungannya.

6. Kesadaran diri menghadapi penyakit yang mengancam hati seperti takabbur, riyā, sum'ah dan lain-lain. ${ }^{72}$

Di awal setiap ibadah, di dalam niatnya, seorang muslim menyatakan bahwa ibadah yang dilakukan adalah "Ii Allāh ta'ālā". Ibadah dilakukan adalah untuk dan karena Allah SWT. Dengan konsep li Allāh ta'àlā ini seorang muslim belajar menghilangkan "selain Allah" seperti takabbur, riyā', sum'ah dari hatinya.

Selain nilai-nilai tersebut, masih banyak nilai pendidikan agama Islam yang bisa kita gali dari niat. Nilai-nilai tersebut dapat dicapai jika seorang memahami apa yang ia nyatakan dalam niatnya, menghayati dan mengambil pelajaran. Jika tidak demikian, maka niat dan ibadahnya hanya menjadi ritual yang tidak ada makna dalam meningkatkan kualitas diri maupun lingkungan sosial.

\section{Simpulan}

Niat adalah al qasd (kesengajaan hati) keinginan yang berbarengan dengan awal suatu perbuatan. Niat sangat penting untuk menentukan sah atau tidaknya suatu ibadah atau membedakan tingkatan suatu ibadah.

\footnotetext{
${ }^{70}$ Muhammad bin Yūnus Al Suwaisy, Majāl ... hlm. 38

${ }^{71}$ Muhammad bin Yūnus Al Suwaisy, Majāl hlm. 38

72 'Umar Sulaymān al Ashqar, al Niyyāt... hlm. 83
} 
Memulai sesuatu dengan niat menimbulkan interesting dan fokus pada suatu 'amal yang berdampak kepada kesiapan hati untuk melakukannya. Kesiapan hati ini penting sebab hati merupakan suatu tempat di mana ị̣lạs sebagai muara dari segala ibadah berada. Dengan siapnya hati diharapkan suatu 'amal dapat dilakukan dengan maksimal.

Niat tidak hanya sekedar ritual ibadah namun banyak nilai pendidikan agama Islam yang didapat dari niat. di antaranya adalah ketundukan dan ketaatan pada perintah agama, mentaati peraturan, tumbuhnya semangat untuk mencapai tujuan yang baik, tekat dan semangat menuju kebaikan, kesabaran dan kemauan yang kuat untuk melakukan sesuatu yang baik meski berat dan sulit, kesadaran untuk meningkatkan kualitas keimanan dan ketaqwaan, kepedulian pada diri maupun lingkungan, kewaspadaan untuk menghindar atau menghadapi penyakit hati, kedisiplinan, kebijaksanaan, cinta-kasih dan kepatuhan pada perintah agama.

\section{Saran}

Kita sebagai umat Islam terkadang hanya memandang ibadah (niat termasuk di dalamnya) sebagai sebuah ritual yang tidak bermakna sehingga ibadah tidak berdampak pada peningkatan kualitas keimanan, ketaqwaan maupun karakter. Seharusnya kita memandang ibadah sebagai bentuk pendidikan Allah SWT kepada kita sehingga dengan melaksanakan ibadah maka kualitas dan kapasitas diri kita akan meningkat.

Wa Allāh a’lam bi al sawāb 


\section{DAFTAR PUSTAKA}

Ashqar, Umar Sulaymān al. 2005. Al Niyyāt fi al 'Ibādàt terj. Oleh Faisal Saleh. Jakarta: Gema Insani Press.

Bukhāry, al. 1422 H. Saḥịh al Bukhāry Juz 1. Dār Ṭawq al Najạ̣

Daḥlān, Al Shaikh Ihsān Muhammad. Tt. Sirāj al Ṭālibīn Juz 1. Dār al Fikr

Dier, Wayne W. 2008. The Power of Intention terj. Quwwah al 'Azimah. Saudi Arabia: Maktabah Jarir

Dimyātiy, Abu Bakr al. Tt. I'ānah al Ṭâlibīn Juz 1. Mawqi' Ya'sūb

Ghazāly, Al. 1424 H/2003 M. Al Arba'īn fì Ușūl al Dỉn. Damaskus: Dār al Qalam

Ḥākim, Al. 1411 H/1990 M. al Mustadrak 'ala al Șahiḥaīn Juz ${ }^{-}$. Beirut: Dār al Kutub al 'Ilmiyyah

Ḥāzimy, Khālid al. 1420 H/2000 M. Ușūl Al Tarbiyah Al Islāmiyyah. Madinah: Dār Ālam Al Kutub

Hajjāj, Muslim bin. Tt. Ṣahịḥ Muslim Juz 8. Beirut: Dār al Āfāq al Jadidah

Ḥusainy, Assayyid Ahmad Bik al. 1320 H/1903 M. Nihāyah al Ahkām fì Bayān mā li al Niyyah min al Aḥkām. Mesir: Mạtba'ah al Kubrā al Amīriyyah

Hājj, Ibn Al. tt. al Madkhal ilā Tanmiyah al A'māl Juz 1. Kairo: Maktabah Dār al Turāth

Hanbal, Ahmad bin. Tt. Musnad al Imām Ahmad bin Hanbal Juz 4. Kairo: Mu'assasah Qurtubah

'Idrūs, Muhammad bin 'Alawy bin Umar Al. 1424 H/2003 M Kitāb al Niyyāt. Yaman: Tarim li al Dirāsāt wa al Nashr

Jamal, Al Shaikh Sulaimān al. Tt. Hāshiyah al Jamal Juz 2. Beirut: Dār al Fikr

Juhany, Nāyif al. 2017. Kārma al Niyyah. Saudi Arabia: Shirkah Ikshif Dhātak

Kathīr, Ibn. 1420 H/1999 M. Tafsìr Al Qur'ān Al Ażīm Juz 6, (Dār Ṭaibah li An Nashr wa al tawzì'

Mājah, Ibn. Tt. Sunan Ibn Mājah Juz 2. Beirut: Dār al Fikr

Qarāfy, Al. 1408 H/1988 M. al Umniyyah fi Idrāk al Niyyah. Riyaḍ: Maktabah al Haramayn

Qarḍ̄wy, Yūsuf Al. Tt. Tamyīz Fiqh Al Sulūk ila Allāh fi Dau' al Qur'ān wa al Sunnah fi al Taríq ila Allāh: al Niyyah wa al Ikhlas. Mu'assasah al Risālah 
Salām, Ibn 'Abd al. Tt. Tafsir Ibn 'Abd al Salām Juz 8

Suwaisy, Muhammad bin Yūnus Al. 1431 H/2010 M. Majāl al Niyyah fi Al Fiqh Al Islāmy. Tunisia: Dār Sukhnūn li al Nashr wa al Tawzì'

Suyūty, Al. 1405 H/1985 M. Al Khạāàịs al Kubrā Juz 2. Beirut: Dār al Kutub al 'Ilmiyyah www.quran.kemenag.go.id

Yamāny, Syekh Yahya ibn Hazah Al. 2012. Tasfiyah al Qulūb min Daran al Awzār wa al Dhunūb (Pelatihan Lengkap Tazkiyah al Nafs terj. oleh Maman Abdurrahman as Segaf). Jakarta: Zaman

Zubaidy, Assayyid Muhammad Al Husaini Al. 1414 H/1994 M. Ithaf Al Sädah Al Muttaqīn Juz 10. Beirut: Muassasah al Tarikh al Araby

Zuhaily, Wahbah al. Tt. Al Fiqh Al Islāmy wa Adillatuh Juz 1. Damaskus: Dār al Fikr. 